J. Perinat. Med. 13 (1985) 245

\section{Perinatal aspects of pregnancy complicated by fetal ovarian cyst}

\author{
P. Kirkinen, P. Jouppila
}

Department of Obstetrics and Gynecology, University of Oulu, Finland

\section{Introduction}

Fetal ovarian organs are not inactive. In fact, they undergo great functional development. $\mathrm{Pa}$ thological changes are possible during this process. The occurrence of a neonatal ovarian cyst is a recognized but rare pediatric phenomenon. Autopsy material of stillbirths and neonatal deaths reveal that small follicular cysts are not unusual in fullterm infants [6]. Only large or complicated cysts are diagnosed and recorded by clinical means, and the true incidence of these neonatal findings has remained unknown. Until the middle of the 1980's fewer than 100 cases have been reported in the literature $[2,3$, $12]$.

A few cases of antenatal ultrasonic diagnosis of a fetal ovarian cyst have been reported [5, 7], but there is minimal experience with the therapeutic or perinatal aspects in these cases. A recent increase in the use of obstetrical ultrasound enables the diagnosis of clinically latent fetal abnormalities. We wish to present our experiences with the diagnostic and therapeutic aspects of fetal ovarian cysts.

\section{Patients and methods}

The material consists of eight pregnancies in which antenatal real-time ultrasonic examination (Toshiba SAL $20 \mathrm{~A}, 3,5 \mathrm{MHz}$ linear probe and Aloka SSD 280, 3,5 MHz linear/sector probe) demonstrated reliable suggestion of fetal ovarian cyst. The following findings were needed for the diagnosis: a female fetus with unior bilateral cystic pelvic tumor, normal fetal kidneys and urinary bladder, and normal ultrasonic appearance of the fetal gastrointestinal tract and abdominal wall. This suspected diagnosis was established in all cases by postnatal examinations or during exploratory surgery. The patients were selected from a population of 21000 parturients from 1978 to 1983 in the Department of Obstetrics and Gynecology, University of Oulu.

\section{Results}

The indications of the antenatal ultrasonic examinations, ante- and postnatal findings and pre- and postnatal courses are presented in Tab. I. The typical ultrasonic appearance of the cyst is presented in Figs. 1-6. In one patient (case number 6) the ovarian cyst underwent twisting and became necrotic. Antenatal ultrasonography revealed slight echodense material and septa (Fig. 7).

Pregnancy was clinically uncomplicated in 7 patients. The above-mentioned pregnancy with the twisted cyst resulted in a spontaneous premature birth during the 34th gestational week. Elective cesarean section was performed due to the large size of the cyst in the 40th gestational week in one instance (case 8). In another patient (case 2) cesarean section was performed because of a breech presentation. 


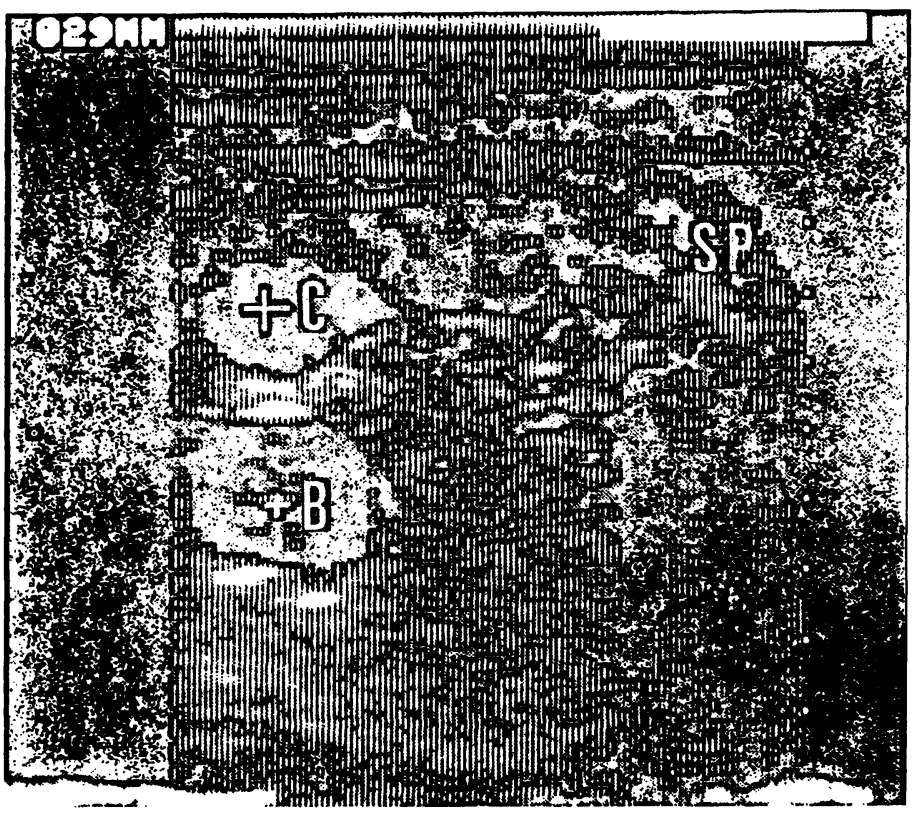

Fig. 1. A transversal ultrasonic scan of fetal body on the 35th gestational week. The cystic finding (C) to the right from the fetal urinary bladder (B) originates from fetal ovarian cyst. SP = spine.

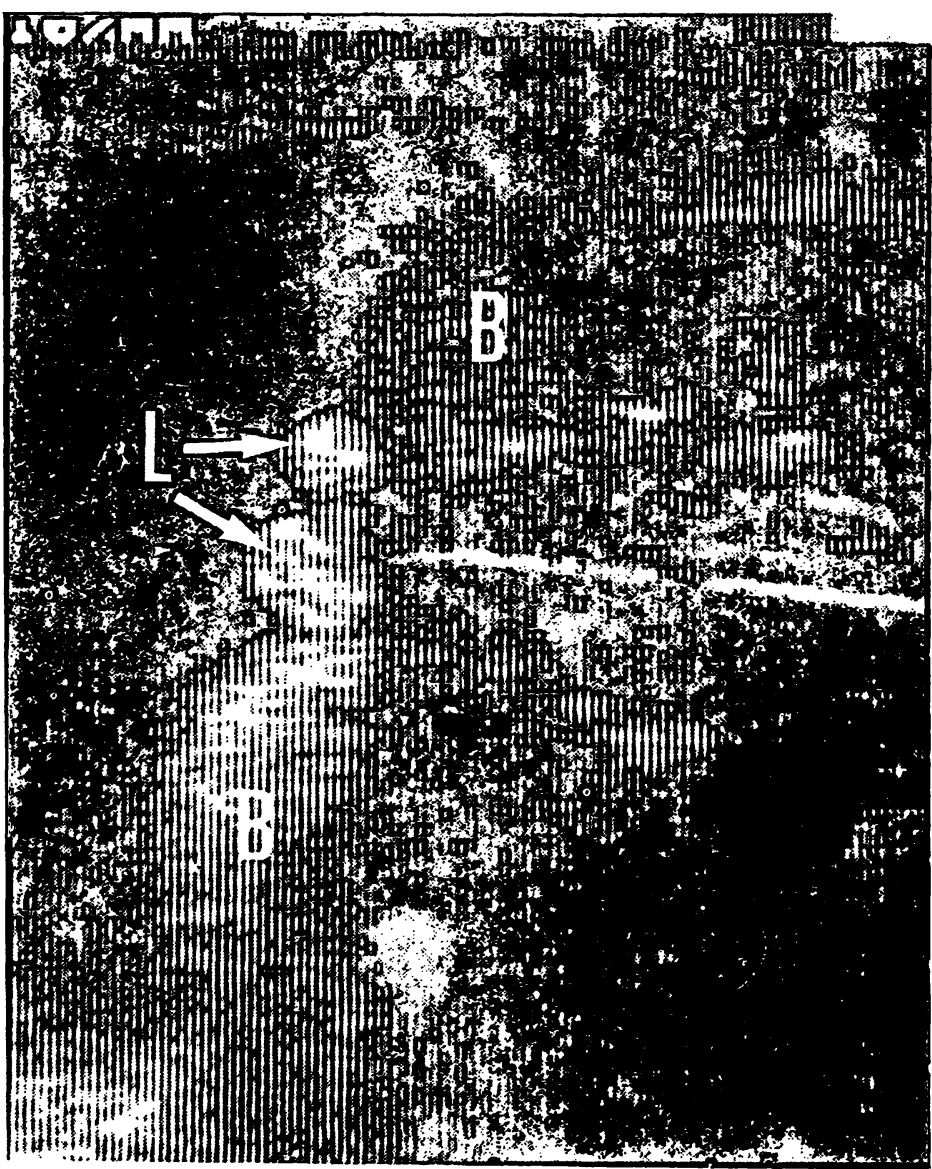

Fig. 3. Female external genitalia (L) of the fetus. $\mathrm{B}=$ buttocks.

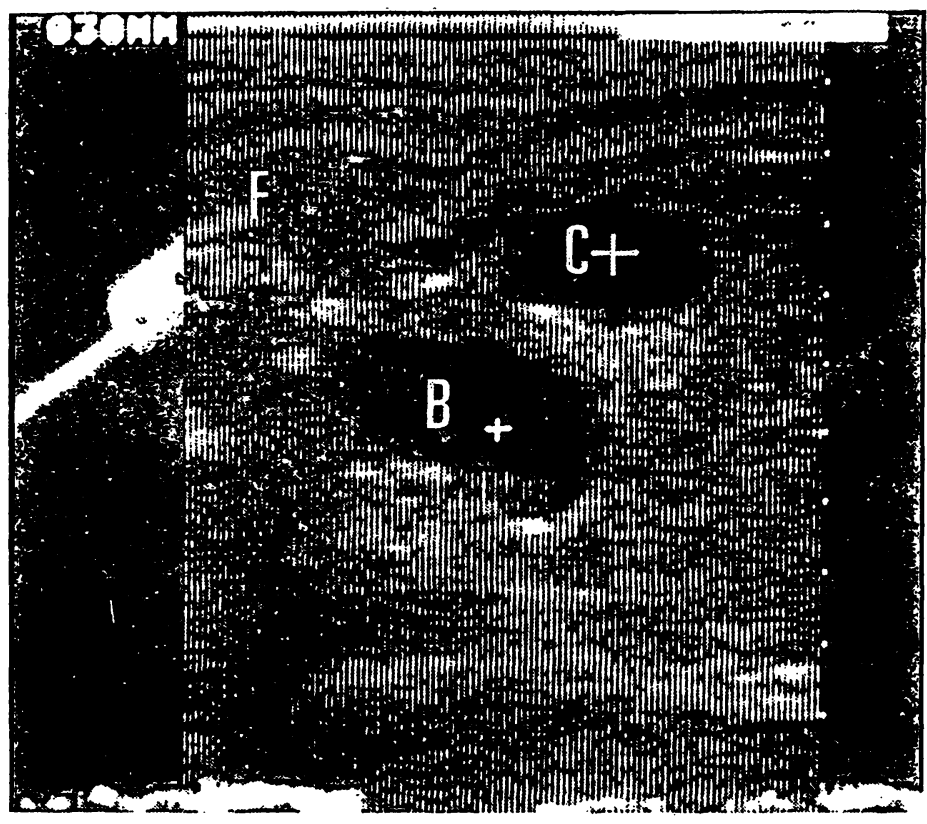

Fig. 2. The corresponding longitudinal scan than in the figure $1 . \mathrm{B}=$ fetal urinary bladder, $\mathrm{C}=$ ovarian cyst, $\mathrm{F}=$ femur.

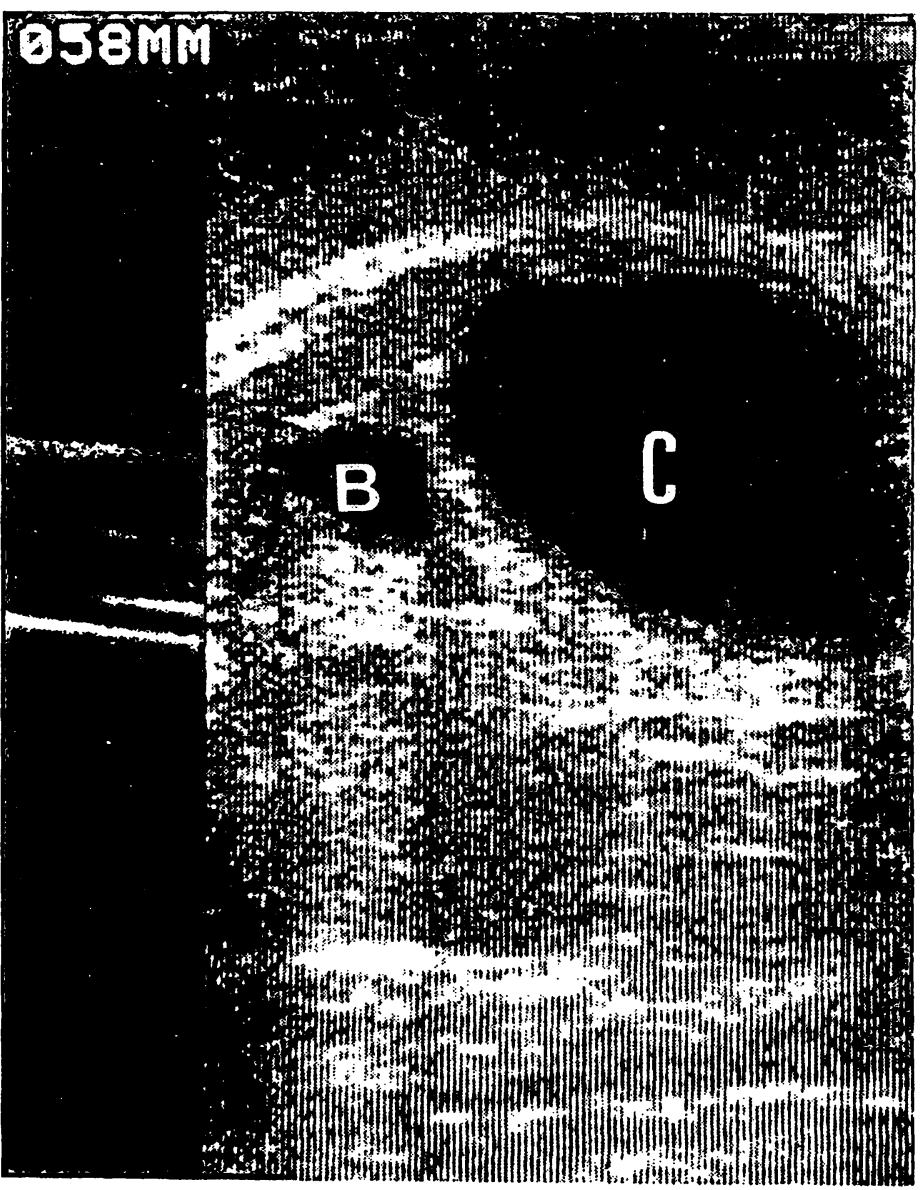

Fig. 4. Large fetal ovarian cyst. A transversal ultrasonic scan of fetal pelvis on the 38 th gestational week. $\mathrm{C}=$ ovarian cyst, $\mathrm{B}=$ urinary bladder. 


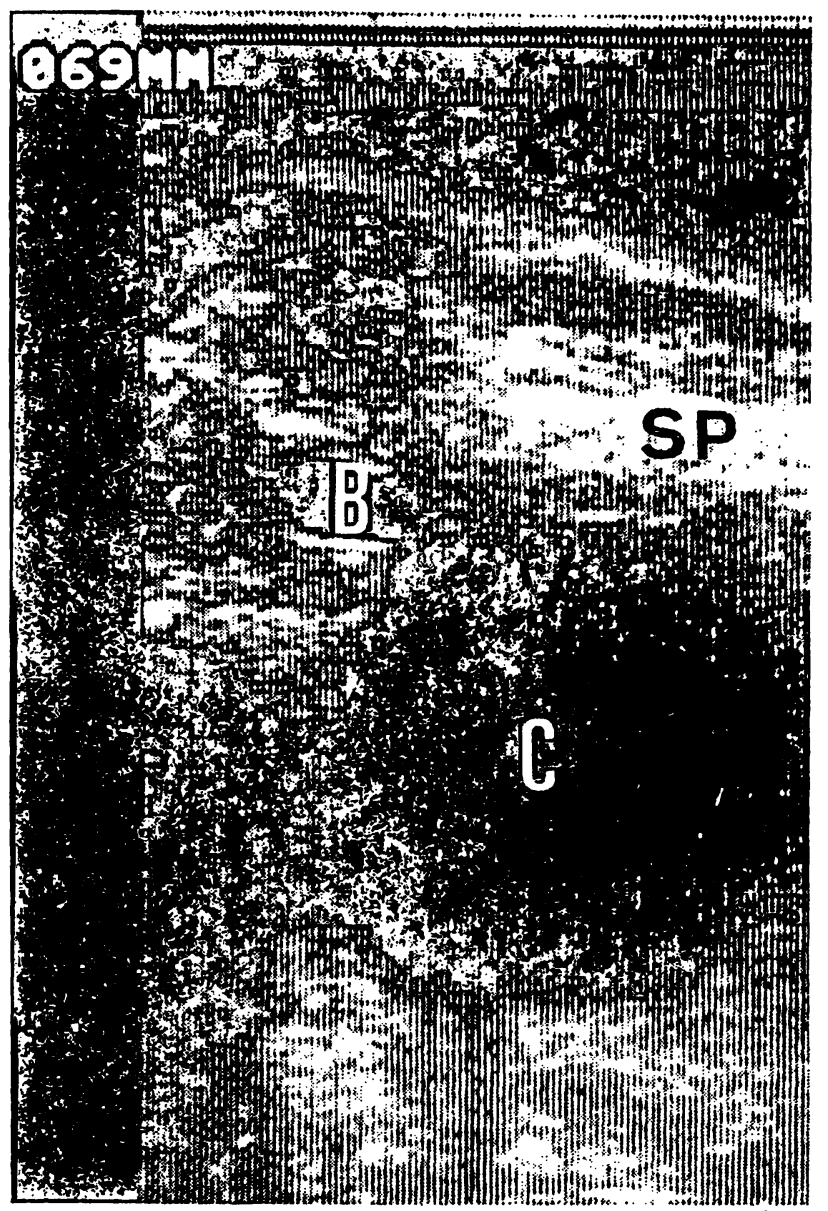

Fig. 5. The corresponding longitudinal scan than in figure 4 . $\mathrm{C}=$ ovarian cyst, $\mathrm{B}=$ urinary bladder, $\mathrm{SP}=$ spine.

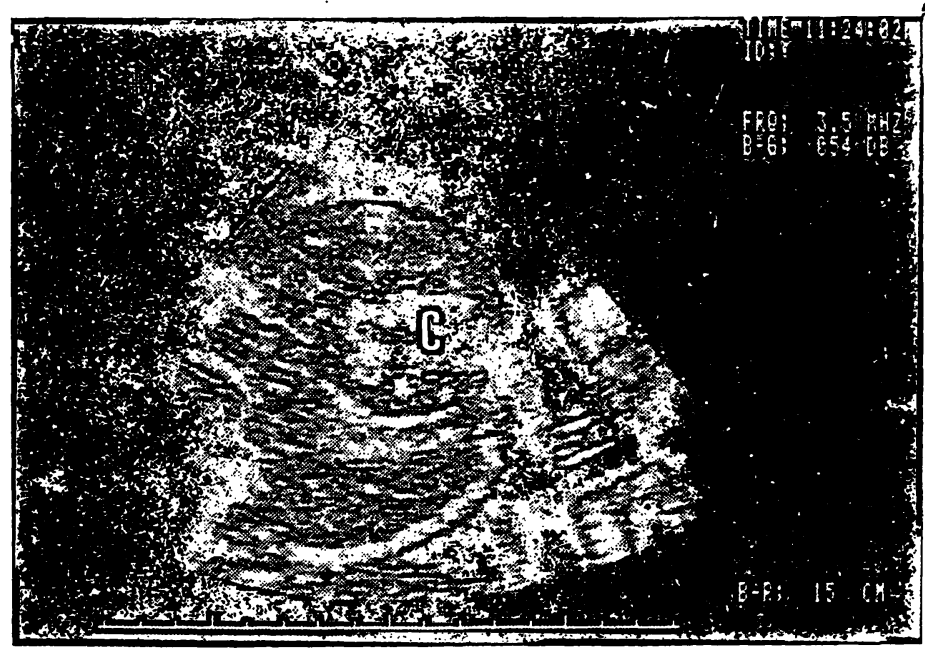

Fig. 7. A twisted fetal ovarian cyst (C). A transversal ultrasonic scan of fetal abdomen on the 33rd gestational week.

All newborns were born in good condition with normal ( $\geq 7$ ) Apgar scores. Surgical management was chosen for three neonates. In case number 8 the indication was the large size of

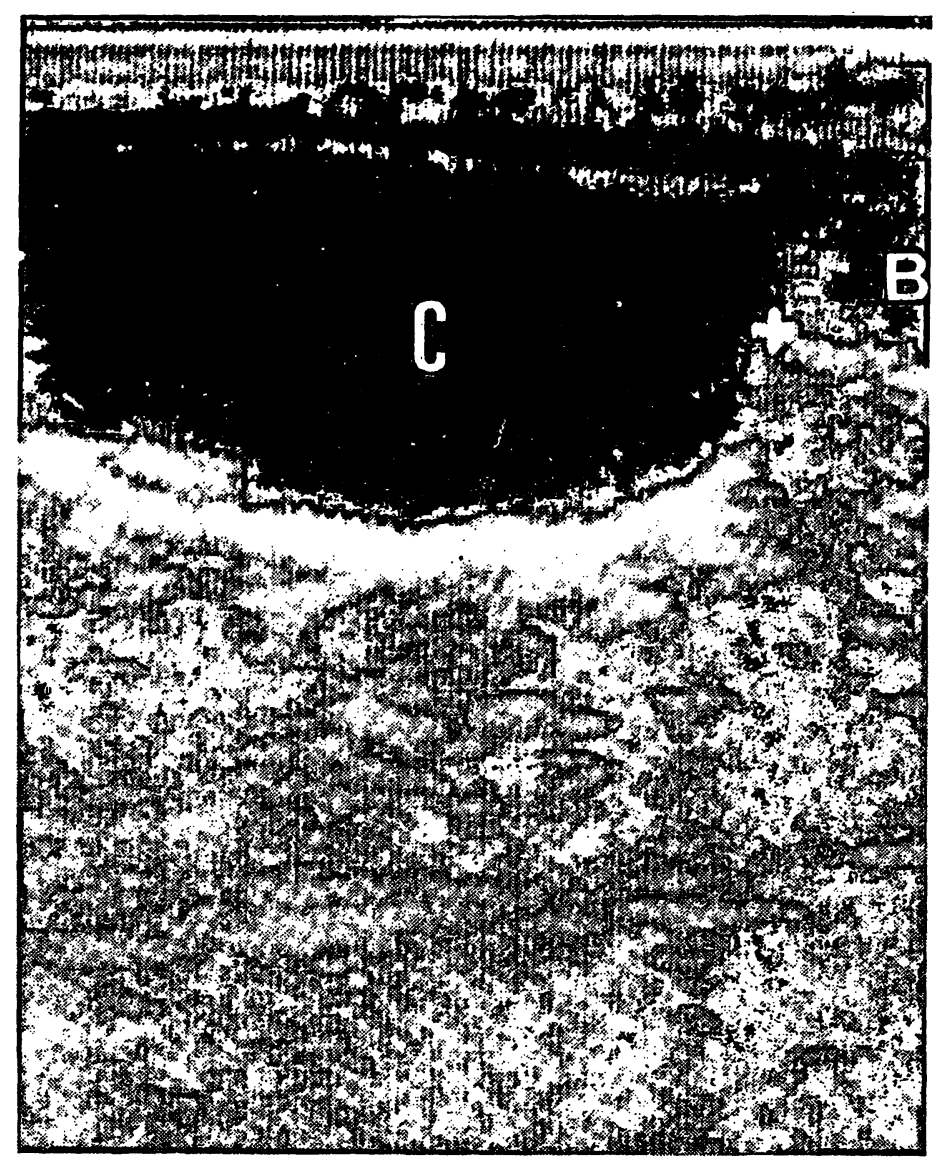

Fig. 6. A longitudinal ultrasonic scan of the newborn, the same case than in Figs. 4 and 5. $\mathrm{C}=$ ovarian cyst, $\mathrm{B}=$ urinary bladder.

the ovarian tumor. In case number 2 the indication for the operation was the presence of relatively large bilateral cysts with slight renal compression. In both instances, local excision of the cysts was performed. Histopathological examination of the resected material revealed follicular cysts. Theca-lutein cells lined the first cyst and in the other case, granulation tissue: The third surgically treated neonate (case 6) postnatally presented similar ultrasonic finding of the cyst as the antenatal findings (echodense material and septa). Surgery at the age of three days revealed that the ovarian cyst contained necrotic substance. No vital ovarian tissue was recognizable on the affected side. The cystic tumor was twisted many times around the ligament. The ovary was normal. Oophorectomy was performed on the affected side. Histopathological examination revealed necrotic cystic ovarian tumor without any specific epithelial findings. 
One newborn managed conservatively presented slight, temporary abdominal tenderness for the first two days. A palpable abdominal mass was found immediately after birth, but disappeared during the first day. The cystic finding of the antenatal ultrasonography was not seen on the second postnatal day. The clinical dia- gnosis was ruptured cyst. All the others, including those with operative treatment, were clinically healthy and symptomless. The infants were followed with one week to three month intervals of ultrasound examination. The cystic findings disappeared within a few days to 6 months in infants conservatively managed (Tab. I).

Tab. I. Ante- and postnatal findings and treatment. SGA = small-gestational-age; LGA $=$ large-gestational-age; Us $=$ ultrasonic examination.

\begin{tabular}{|c|c|c|c|c|c|c|}
\hline Case & $\begin{array}{l}\text { Antenatal ult } \\
\text { Indication }\end{array}$ & $\begin{array}{l}\text { Gonic examin } \\
\text { week }\end{array}$ & $\begin{array}{l}\text { ion } \\
\text { Finding }\end{array}$ & $\begin{array}{l}\text { Maximal size } \\
\text { of cyst } \\
\text { (cm) }\end{array}$ & $\begin{array}{l}\text { Week and route } \\
\text { of delivery }\end{array}$ & $\begin{array}{l}\text { Postnatal findings } \\
\text { and treatment }\end{array}$ \\
\hline 1. & $\begin{array}{l}\text { SGA- } \\
\text { suspiction }\end{array}$ & 36 & $\begin{array}{l}\text { one left } \\
\text { ovarian cyst }\end{array}$ & $4 \times 4$ & $\begin{array}{l}41 \text {, spontaneous } \\
\text { vaginal }\end{array}$ & $\begin{array}{l}\text { us: one left ovarian cyst, } \\
2.5 \times 2.5 \mathrm{~cm} \\
\text { conservative treatment } \\
\text { disappeared after } 2 \\
\text { months }\end{array}$ \\
\hline 2. & $\begin{array}{l}\text { breech } \\
\text { presentation }\end{array}$ & 37 & $\begin{array}{l}\text { bilateral } \\
\text { ovarian cyst }\end{array}$ & $\begin{array}{l}6 \times 6 \text { and } \\
2.5 \times 3\end{array}$ & $\begin{array}{l}40 \text {, elective } \\
\text { cesarean section }\end{array}$ & $\begin{array}{l}\text { us: bilateral ovarian cyst } \\
6 \times 6 \text { and } 3 \times 3 \mathrm{~cm} \\
\text { resection at } 8 \text { days } \\
\text { of age }\end{array}$ \\
\hline 3. & $\begin{array}{l}\text { suspicion of } \\
\text { postmaturity }\end{array}$ & 41 & $\begin{array}{l}\text { one left } \\
\text { ovarian cyst }\end{array}$ & $4 \times 4$ & $\begin{array}{l}42 \text {, spontaneous } \\
\text { vaginal }\end{array}$ & $\begin{array}{l}\text { us: one left ovarian cyst } \\
4 \times 5 \mathrm{~cm} \\
\text { conservative treatment, } \\
\text { disappeared after } 1 \text { week }\end{array}$ \\
\hline 4. & $\begin{array}{l}\text { routine scan } \\
\text { in normal } \\
\text { pregnancy }\end{array}$ & 35 & $\begin{array}{l}\text { one left } \\
\text { ovarian cyst }\end{array}$ & $4.5 \times 3.5$ & $\begin{array}{l}41 \text {, spontaneous } \\
\text { vaginal }\end{array}$ & $\begin{array}{l}\text { palpable abdominal } \\
\text { mass and distention for } \\
\text { the first } 2 \text { days } \\
\text { conservative treatment } \\
\text { us: normal at } 3 \text { days } \\
\text { of age }\end{array}$ \\
\hline 5. & $\begin{array}{l}\text { LGA- } \\
\text { suspicion }\end{array}$ & 32 & $\begin{array}{l}\text { one right } \\
\text { ovarian cyst }\end{array}$ & $2 \times 3$ & $\begin{array}{l}38, \text { spontaneous } \\
\text { vaginal }\end{array}$ & $\begin{array}{l}\text { us: one right ovarian } \\
\text { cyst } 4 \times 5 \mathrm{~cm} \\
\text { conservative treatment, } \\
\text { disappeared after } \\
2 \text { weeks }\end{array}$ \\
\hline 6. & slight edema & 32 & $\begin{array}{l}\text { one left } \\
\text { ovarian cyst }\end{array}$ & $\begin{array}{l}5 \times 5 \\
\text { septas and } \\
\text { echodense } \\
\text { material inside }\end{array}$ & $\begin{array}{l}34 \text {, premature } \\
\text { vaginal }\end{array}$ & $\begin{array}{l}\text { us: ovarian tumor, } \\
6 \times \mathrm{cm} \\
\text { oophorectomy; one left } \\
\text { ovarian cyst at } 3 \text { days } \\
\text { of age (twisted ovarian } \\
\text { cyst) }\end{array}$ \\
\hline 7. & $\begin{array}{l}\text { breech } \\
\text { presentation }\end{array}$ & 36 & $\begin{array}{l}\text { bilateral } \\
\text { ovarian cyst }\end{array}$ & $3 \times$ and $5 \times 5$ & $\begin{array}{l}39 \text {, spontaneous } \\
\text { vaginal }\end{array}$ & $\begin{array}{l}\text { us: bilateral ovarian } \\
\text { cyst, } 2 \times 2 \mathrm{~cm} \\
\text { conservative treatment, } \\
\text { disappeared after } 3 \\
\text { months }\end{array}$ \\
\hline 8. & $\begin{array}{l}\text { LGA- } \\
\text { suspicion }\end{array}$ & 35 & $\begin{array}{l}\text { one left } \\
\text { ovarian cyst }\end{array}$ & $8 \times 10$ & $\begin{array}{l}\text { 39, elective } \\
\text { cesarean section }\end{array}$ & $\begin{array}{l}\text { us: one left ovarian cyst, } \\
8 \times 10 \mathrm{~cm} \\
\text { resection at } 10 \text { days } \\
\text { of age }\end{array}$ \\
\hline
\end{tabular}


Postnatal ultrasound and x-ray examination revealed a dual renal pelvis and ureteral system on the opposite side of the cyst in one newborn, and in one neonate there was slight dilatation of the pelvis of the other kidney. Otherwise, all the newborns were healthy with normal postnatal development.

\section{Discussion}

Seven of our eight cases demonstrated a normal antenatal course of pregnancy. The neonatal clinical condition was normal, although in half it was possible to palpate a mass inside the abdominal cavity. The antenatal diagnosis of pelvic cyst was incidentally made by ultrasonic examination in all cases. This strongly suggests that the true incidence of fetal ovarian cysts may be somewhat greater than earlier supposed particularly since the present series was collected in a relatively short period and from a relatively small population. Fortunately, the normal course of these cysts most often seems to be postnatal involution and regression $[1,3]$. This also was noted in our cases. A large number may remain undiagnosed if routine screening during late pregnancy is not done. The main complications of these cysts, namely torsion and rupture and secondary complications caused by bowel obstructions, may have great postnatal clinical importance $[2,3,10,13]$. This stresses the importance of prenatal diagnosis to allow appropriate pediatric observation and to avoid accidental and unexpected postnatal catastrophes. Rather large cysts seem to be symptomless both ante- and postnatally, but vaginal delivery may initiate hemorrhage as was noted in one of our cases. We also found one antenatal complication of the cyst, torsion and necrosis. This was associated with premature delivery. This complication possibly was an etiological factor for the premature contractions. A few fetal ovarian cyst cases associated with polyhydramnios have been reported earlier [3]; however, we did not find polyhydramnios in our cases.

In our series even the larger cysts had postnatal spontaneous resolution without significant clin- ical difficulties. The birth physiologic status of these infants was normal. At this moment it is not possible to predict if some of these infants will have disturbances in the ovarian-pituitary function during their fertile years.

The site of origin for an antenatal cyst within fetal peritoneal cavity or fetal abdominal walls may be from many organs. The majority of large palpable neonatal masses is said to be of renal origin [9]. Other intra- and retroperitoneal organs may also contain cystic lesions [4, 8]. Thus, an absolute definitive differential diagnosis of fetal ovarian cyst is difficult. We feel that the findings of female external genitalia, normal urinary bladder and kidneys, and normal gastrointestinal tract with clinically normal pregnancy suggest this diagnosis when associated with a fetal pelvic cyst. However, we have also had one incorrect diagnosis due to another fetal genital abnormality. In one fetus a hematome-

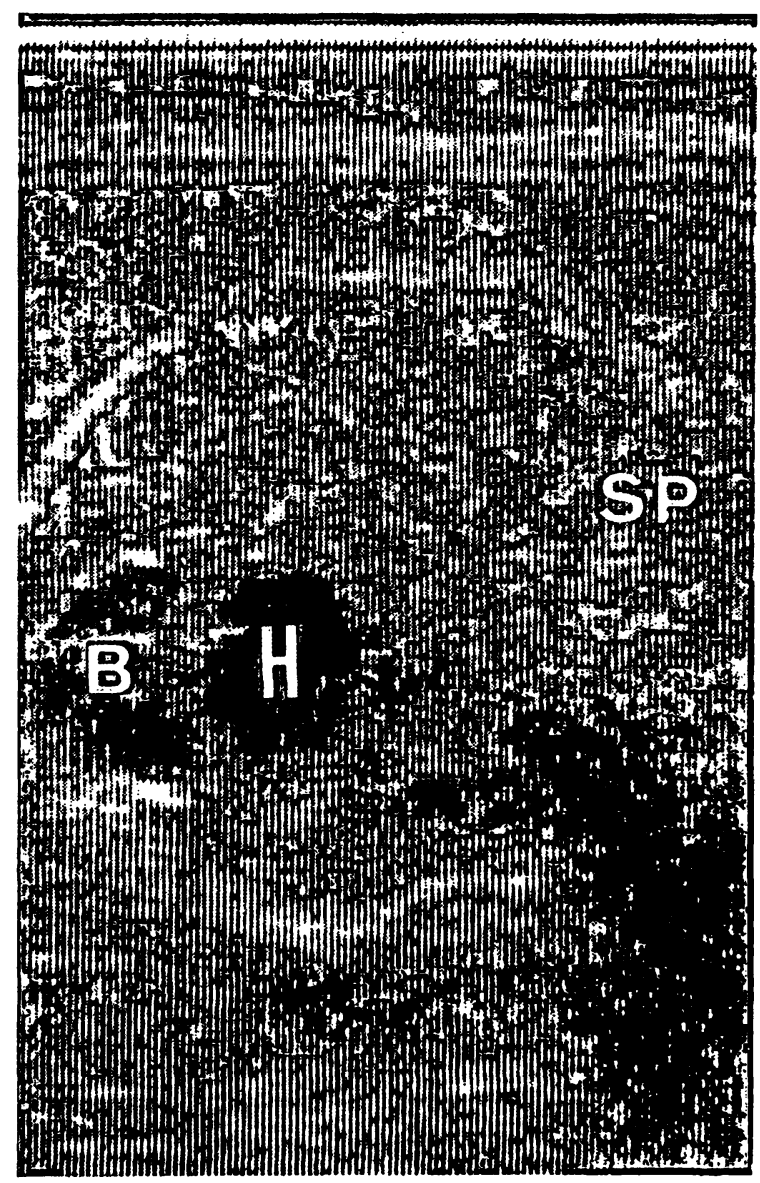

Fig. 8. Fetal hematometra $(\mathrm{H})$. A transversal ultrasonic scan on the 36th gestational week. B = urinary bladder, $\mathrm{SP}=$ spine. 
tra was associated with vaginal atresia. This pelvic cyst was located directly dorsal to the fetal bladder. It was erroneously diagnosed as a fetal ovarian cyst (Fig. 8). The antepartun diagnosis must always be substantiated by postnatal evaluation. Repeat ultrasound monitoring is needed until cystic findings disappear. Surgery is required if the lesion does not regress.

We did not find any etiological factor for the cysts. In all pregnancies the fetoplacental function monitored by hPL and serum estriol assays, and cardiotocography was normal. None of the mothers utilized a specific teratogenic medication. The diagnoses were made in the third trimester. The fetal ovaries normally contain primordial and primary follicles and even atretic scars of follicles in this phase [11]. The gestational period, isolated nature of the cysts, the good postnatal spontaneous resolu- tion and luteinization within the cystic walls point to some functional effect during pregnancy as the etiological factor.

Clinically the most important point is the possibility of ovarian etiology associated with this type of fetal ultrasonic finding. Many authors have recommended surgical approach for treatment of a palpable neonatal abdominal mass $[2,12,13]$. We feel that if the mass is cystic without solid components at ultrasonography without clinical complications and the cyst is of ovarian origin on the basis of postnatal examinations, many such patients can be managed conservatively. Small and unpalpable cysts can also be conservatively followed in most cases. If the cysts do not show rapid spontaneous involution, operative treatment is needed. Similarly, if solid components are inside the cyst, a functional etiology is unlikely and surgical approach is necessary.

\section{Summary}

Fetal ovarian cyst was diagnosed by antenatal ultrasonic examination in eight pregnancies. In one case the cyst was antenatally twisted and necrotic, and the pregnancy resulted in premature birth during the 34th week. The other cases had clinically normal antenatal courses. One cyst ruptured at birth. The clinical condition of this and all the other neonates was good. Three of the neonates were managed surgically and five by conservative follow-

up with repeated ultrasonic examinations. Cystic tumors of these infants disappeared without clinical complications in the subsequent six months. An ovarian etiology for cystic pelvic tumor of a female fetus should be considered. Conservative treatment after birth is possible in many cases with spontaneous involution likely during the first months of life.

Keywords: Fetal abnormality, newborn, ovarian cyst, ultrasound.

\section{Zusammenfassung}

Perinatale Aspekte der Schwangerschaft mit fetaler Ovarialzyste

Bei 8 Schwangerschaften wurden durch antenatale Ultrasonographie fetale Ovarialzysten diagnostiziert. In einem Fall kam es zu einer antenatalen Torsion und Nekrose der Zyste und zu einer Frühgeburt in der 34. Woche. Die übrigen Schwangerschaften verliefen klinisch unauffällig. In einem Fall rupturierte eine Zyste unter der Geburt. Der klinische Zustand dieses Kindes sowie der übrigen Neugeborenen war gut. 3 Neugebore- ne wurden einer chirurgischen Behandlung unterzogen; bei den übrigen wurde unter ultrasonographischer Kontrolle konservativ vorgegangen. Die zystischen Tumore dieser Kinder bildeten sich innerhalb von 6 Monaten ohne klinische Komplikationen zurück. Diagnostiziert man einen zystischen Beckentumor bei einem weiblichen Feten, sollte man stets an das Ovar als Ausgangspunkt denken. Ein konservatives Vorgehen ist in vielen Fällen möglich, da eine spontane Rückbildung während der ersten Lebensmonate sehr wahrscheinlich ist.

Schlüsselwörter: Fetale Mißbildung, Neugeborenes, Ovarialzyste, Ultraschall. 


\section{Résumé}

Aspects périnataux de la grossesse compliquée du kyste ovarien fetal

On a diagnostiqué par échographie anténatale un kyste ovarien fætal au cours de 8 grossesses. Dans un cas, le kyste était tordu et nécrotique avant la naissance, et la grossesse a abouti à une naissance prématurée au cours de la 34ème semaine. Les autres cas ont eu une évolution anténatale cliniquement normale. Un kyste s'est rompu à la naissance. L'état clinique dans ce cas et chez tous les autres nouveaux-nés était bon. Trois nouveaux-nés ont ćté opérés et 5 ont eu une surveillance conservatrice avec des échographies répétées. Les kystes de ces enfants ont disparu sans complications cliniques, au cours des 6 mois suivants. On devrait se souvenir chez les fetus féminins de l'étiologie ovarienne en face d'une tumeur pelvienne kystique. Le traitement conservateur après la naissance est possible dans de nombreux cas et l'involution spontanée est probable au cours des premiers mois de la vie.

Mots-clés: Anomalie fœtale, kyste ovarien, nouveau-né, ultrasons.

\section{Bibliography}

[1] Ahlvin, R., W. BAuER: Luteinized cysts in ovaries of infants born of diabetic mothers. Am. J. Dis. Child. 93 (1957) 107

[2] AHMED, S.: Neonatal and childhood ovarian cysts. J. Pediatr. Surg. 6 (1971) 702

[3] Bower, R., L. Deriner, J. Ternberg: Bilateral ovarian cysts in the newborn. Am. J. Dis. Child. 128 (1974) 731

[4] Campbell, S., J. Pearce: The prenatal diagnosis of fetal structural anomalies by ultrasound. Clin. Obstet. Gynecol. 10 (1983) 475

[5] Crade, M., M. Gillooly, K. Taylor: In utero demonstration of an ovarian cystic mass by ultrasound. J. Clin. Ultrasound 8 (1980) 251

[6] DeSA, D. J.: Follicular ovarian cysts in stillbirths and neonates. Arch. Dis. Child. 50 (1975) 45

[7] JOUPPILA, P., P. KIRKINEN, S. TUONONEN: Ultrasonic detection of bilateral ovarian cysts in the fetus. Eur. J. Obstet. Gynaecol. Reprod. Biol. 13 (1982) 87

[8] KurJaK, A., V. Latin, V. D'AdDario: Abnormalities of the fetus, placenta and umbilical cord. Prog. Med. Ultrasound 3 (1982) 87
[9] LoNGINo, L., L. MARTIN: Abdominal masses in the newborn infant. Pediatrics 21 (1958) 596

[10] Mainolfi, F., W. Standiford, T. Hubbard: Ruptured ovarian cyst in the newborn. J. Pediatr. Surg. 3 (1968) 612

[11] Pelliniemi, L., D. Martin: The fetal gonadal and sexual differentiation. In: TULCHINSKY \& RYAN (eds.): Maternal - fetal endocrinology. Saunders Company, Philadelphia 1980

[12] TOWNE, B., H. MahOuR, M. Woolley et al.: Ovarian cysts and tumors in infancy and childhood. J. Pediatr. Surg. 10 (1975) 311

[13] WelCh, K. J.: Ovarian cysts and tumors. In: Ravitch, Welch, Benson et al. (eds.): Pediatric Surgery. Year Book of Medical Publishers, Inc., Chicago 1979

Received September 10, 1984. Accepted January 30, 1985.

P. Kirkinen, M. D.

Department of Obstetrics and Gynecology

University of Oulu

90220 Oulu 22

Finland 


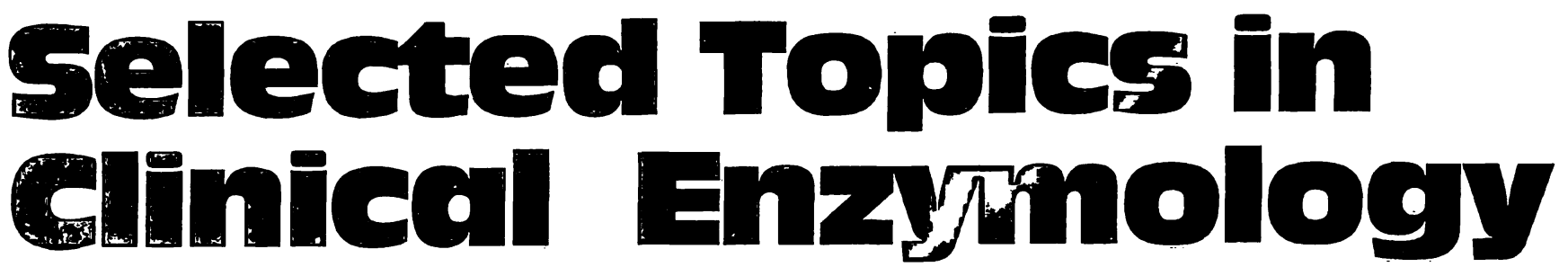

Molume 2

Proceedings (selected) of the Fourth International Congress on Clinical Enzymology - Washington, D.C., U.S.A., July 30-August 2, 1983

Editors M. Werner, D. M. Goldberg

1984. $17 \mathrm{~cm} \times 24 \mathrm{~cm}$. XXII, 667 pages. Numerous illustrations. Hardcover. DM 260,ISBN 3110102331

This book covers practical and theoretical aspects of enzymology. Over 50 contributions by an international array of experts bring together current developments in analytical methodology, diagnostic use of enzymes, the role of enzymes in pathophysiology, pharmacology and therapeutics as well as veterinary medicine. A special section is devoted to emerging insights on enzyme heterogeneity. Each contribution contains an abstract for rapid survey of its contents, and a carefully edited bibliography.

Contents (Main Chapters)

Changing Methods - Diagnosis · Pathophysiology, Pharmacology and Therapeutics · Enzyme Heterogeneity · Veterinary · Subject Index · Index of Contributors.

Also available

\section{Selected Topics in Clinical Enzymology}

Editors D. M. Goldberg, M. Werner

1983. XVIII, 362 pages. DM 160,-

\section{de Gruyter · Berlin · New York}

